\title{
The Effect of Social Networks
}

\section{Advertisements on Egyptian Consumers'} Purchase Behaviour

\author{
Rasha H. A. Mostafa ${ }^{1}$ and Madiha Metawie ${ }^{2}$ \\ ${ }^{1}$ Faculty of Business, Ain Shams University, Egypt \\ dr.rasha.h.mostafa@bus.asu.edu.eg \\ ${ }^{2}$ Faculty of Business, Ain Shams University, Egypt \\ Faculty of Business Administration, Economics and Political \\ Science, British University in Egypt \\ Madiha.metawie@bue.edu.eg
}

\begin{abstract}
The purpose of this study is to examine the effects of perceived advertising value of Social Networks adverts (SN ads) on Egyptian consumers' purchasing behaviour. The researchers based their study on Ducoffe (1996) Advertising Value Model that includes informativeness, entertainment, credibility, and irritation, in addition to materialism and peer influence. Data were obtained from 375 Egyptian respondents. Structural Equation Modelling was applied to examine the research hypotheses. The results supported the positive mediating effect of attitude towards SN ads and purchase intention on the relationship between informativeness, entertainment, irritation, materialism and peer influence on consumers purchasing behaviour. Yet, SN ads credibility deemed insignificant. The results provide significant insights to advertisers with respect to optimising the effect of $\mathrm{SN}$ ads on consumers purchasing behaviour. Additionally, it extends Ducoffe model by adding materialism and peer influence. Finally, it validates the Theory of Reasoned Action in the Egyptian context.
\end{abstract}


Keywords: Advertising Value, Materialism, Peer Influence, Attitude, Intention, Purchase Behaviour, Social Networks ads, Social Media, Egypt.

\section{INTRODUCTION}

The rapid advance in Internet technology has allowed for the exponential growth of online social media platforms (Stelzner, 2014; Duffett, 2015). Since its introduction, social media has received much attention as it altered the way organizations are doing business (Boateng \& Okoe, 2015; Diwakar, 2016). Thanks to Web 2.0 that allows individuals to interact in two way communications, to like, and to post reviews on products and services, which led marketers to quickly realize its influential effect on customers purchasing decisions (Patino, Pitta, \& Quinones, 2012). In addition, Web 2.0 is effective in tracking customers' behavioural responses (Logan, Bright, \& Gangadharbatla, 2012; Boateng \& Okoe, 2015). Therefore, the social media forces the organizations to adopt it as part of their marketing communications mix (Logan et al., 2012).

Consequently, (eMarketer, 2019) underscored that organizations are increasing their social media budgets with digital interactive advertising, where worldwide digital ad spending in 2020 will rise by $15.5 \%$ to reach $\$ 384.96$ billion. Hence, for the first time, digital advertising will account for roughly half of the global ad market. However, Google remained the largest digital ad seller in the world in 2019, accounting for $31.1 \%$ of worldwide ad spending, $\$ 103.73$ billion, followed by Facebook that accounted for almost $20 \%$ of the digital ad seller with $\$ 67.37$ billion in net ad revenues.

These figures have encouraged marketing scholars to investigate the value of advertising on social media (e.g. Facebook, YouTube, LinkedIn, Twitter), and to explore customers 
perceptions and attitudes towards them (Maxwell, 2013; McCarthy et al., 2014).

Consequently, based on Ducoffe $(1995,1996)$ advertising value model, the current research examines the relationship between advertising value and customers' attitude toward social network ads (SN ads) and their purchasing behaviour in the Egyptian context. Nevertheless, most of the studies have focused on developed countries (Wang, S. \& Toncar, 2009), even though some researchers emphasized that consumers' attitude toward social networks ads differs from one country to the other (Durvasula et al., 2001).

Accordingly, the research problem is analyzing which advertising value(s) that best articulates Egyptian consumers attitudes towards social network ads, and consequently, affects their purchasing behavior.

Therefore, investigating Egyptian's consumers' attitude towards social networks ads will contribute to the dearth of literature on developing countries by shedding more light into different cultural context, given that $\mathrm{SN}$ ads in Egypt is still at its infancy. In addition, it will allow practitioners to better understand Egyptian customers' attitude, and behaviour with respect to social networks advertising. Hence, it will provide them with a road map to effectively develop $\mathrm{SN}$ ads campaigns, and to better assess and evaluate them.

The rest of the paper is structured as follows: an overview of the relevant literature on $\mathrm{SN}$ ads is presented from which the conceptual framework and research hypotheses are postulated. Next, the methodology used to guide this research is reviewed, followed by the research findings. Finally, discussion, conclusions, managerial implications and directions for future research are highlighted. 


\section{CONCEPTUAL FRAMEWORK AND HYPOTHESES DEVELOPMENT}

The most commonly used model to clarify user perceptions and attitudes toward Internet advertising is Ducoffe (1996) Advertising Value model. In this model, consumers' Advertising Value is defined as "a subjective evaluation of the relative worth or utility of advertising to consumers". Ducoffe proved the significant impact, either positive or negative, of information, entertainment, and irritation on advertisement value, and the author further confirmed that the latter measure could be applied to Internet advertising, as well as television, indicating that the measure is applicable across media types. Also, Brackett and Carr (2001) in their study on cyberspace advertising reported that information, entertainment, irritation and credibility significantly affect advertisement value, which in turn affects attitude towards advertisements. Similarly, Murillo, Merino, and Nunez (2016) identified the effect of credibility and irritation on users' attitudes toward Twitter advertising. The following sections will further discuss Advertising Value model dimensions, materialism, and peer influence, consumers' attitude towards SN ads, their intentions and actual online purchasing behavior.

\section{Informativeness}

There is consensus among authors that the main function of advertising is to provide consumers with information that help them forming attitude, and subsequent buying behavior toward a product and/or a brand (e.g. Saxena \& Khanna, 2013; Murillo, Merino \& Nunez, 2016; Ducoffe, 1996). In addition, it provides existing and potential consumers with information about alternative products (Gao \& Koufaris, 2006), modified products, along with any changes in the prices (Nwagwu \& Famiyesin, 2016). 
Informativeness feature plays a pivotal role in accelerating the acceptance rate of the advertisement by the consumers (Ducoffe, 1996). For advertisement information to be effective, it has to be up-to-date, timely, easily accessible and relevant to the target audience (Murillo et al., 2016). Accordingly, consumers perceive such advertisements as valuable and worth watching (Saxena \& Khanna, 2013).

Unlike advertisement on traditional platforms or even Web sites, Social Network Sites (SNS) stimulate its users to scan and share information with others online (Muntinga, Moorman \& Smit, 2011). This is basically due to its interactive nature (Saxena \& Khanna, 2013). Hence, allow SN ads information to become viral (Logan, Bright and Gangadharbatla, 2012), and to be used by large and small companies alike as a competitive tool to reach and strengthen their relationships with their target audience (Jhih-Syuan \& Pena, 2011).

The literature confirmed the significant positive association between online advertisement informativeness and attitude in different milieu as follows: general online ads (e.g. Wang et al., 2009; Wang \& Sun, 2010); mobile phones ads (e.g. Unal et al., (2011); SN ads in general (e.g. Saxena \&Khanna, 2013; Mukherjee \& Banerjee, 2017); Facebook (e.g. Duffet, 2015); Twitter (e.g. Murillo et al., 2016); and YouTube (e.g. Yang, Huang, Yang \& Yang, 2017). Consequently, the following research hypothesis is proposed:

H1: There is a significant positive association between Social Networks ads (SN ads) informativeness and consumers' attitude. 


\section{Credibility}

The credibility-trust relationship forms a dilemma for researchers. Some literature suggests that credibility is a multidimensional construct encompasses trustworthiness; truthfulness; and believability among other dimensions (e.g. Soh, Reid \& King 2007). While others, suggests that trust includes factors not necessarily echoed in credibility for example confidence; reliability; mutual emotional investment amongst others (e.g. Doney \& Cannon, 1997). Hence, there is no universal agreement regarding the relationship between credibility and trust. Yet, most of the social science researches confirm that both concepts should be treated independently (e.g. Soh et al., 2007).

The literature indicated four forms for conceptualizing and measuring credibility as follows: source credibility; general advertising credibility; advertisement content credibility; and media credibility (Soh et al., 2007). The current research is specifically interested in media credibility. The researchers mean by media credibility the channel(s) via which advertisements are delivered to the intended target audience, in our case Social Networks are the ads medium. Customers will have faith in the ad content and pay attention to the advertised product if they do trust the medium itself (Moore \& Rodgers, 2005), and vice versa (Zha, Li \& Yan, 2015).

Numbers of authors have established a positive relationship between ad credibility and attitude. Boateng and Okoe (2015) found a significant positive relationship between credibility and attitudes towards social media advertising. Further, Murillo et al. (2016) indicated that credibility significantly influences perceptions of advertising value after entertainment and informativness, and attitude towards Twitter advertising. The same study displayed gender effects among Mexican Millennials 
where female respondents showed significant association with ad value as opposed to males. Brackett and Carr (2001) noted a relationship between trustworthiness of online advertising and consumers' attitude towards it.

Moreover, mobile advertising was well researched in the literature. There is consensus among authors that credibility plays a key role in developing a positive attitude towards mobile advertising in different countries as follows: Faraz and Hamid (2010) in Iran, Tsang, Ho and Liang (2004) in Taiwan, and Van der Waldt, Rebello, \& Brow, (2009) in South Africa. On the other hand, Wongman (2010) and Nwagwu, and Famiyesin, (2016) reported negative correlation between credibility and attitude towards, and acceptance of mobile advertising in Hong Kong and Lagos, Nigeria respectively.

Hence, the researchers will follow the mainstream emphasized in the literature and hypothesize that:

H2: There is a significant positive association between Social Networks ads (SN ads) credibility and consumers' attitude.

\section{Entertainment}

Ducoffe, (1996) and McQuail (1994) defined advertising entertainment as the fulfillment of consumers' needs in terms of diversion, aesthetic enjoyment or emotional release. Entertainment expresses consumers' sense of pleasure related to messages (Altuna, \& Konuk, 2009). Therefore, informative advertisements that lack entertainment is considered worthless (Saxena \& Khanna, 2013). Consequently, advertisers are very much keen to provide target audience with entertaining ads, which in turn increase the effectiveness of their messages (Logan et al., 2012). Further, the ability of advertising to entertain can enhance ads experience (Saxena \& Khanna, 2013).

Participating and using Social Networks Sites is entertaining, as they have the power to entertain its audience (Logan et al., 
2012). Kim and Lee (2010) noted that college students use SNSs for six main reasons: entertainment, passing time, social interaction, information seeking, information providing, and professional advancement.

Ducoffe (1995) revealed that consumers are more likely to positively evaluate an ad when it is entertaining. Then later in 1996, Ducoffe asserted that perceived levels of entertainment are directly associated with Web advertising. The literature further demonstrated the relationships between perceived entertainment value and overall attitudes towards advertising. There is agreement among authors that entertainment represents one of the strongest predictors of advertising value (e.g. Saxena \& Khanna, 2013; Murillo et al., 2016). Taylor, Lewin, and Strutton (2011) asserted that entertainment affects consumers' attitude towards SNS advertisements four times as much as information. Further, Wong and Tang (2008) and Unal et al. (2011) revealed that the perceived entertainment value of mobile advertisements turned to be one of the most important factors affecting consumers' attitudes towards advertisements. Based on the above, the following hypothesis is proposed:

H3: There is a significant positive association between Social Networks ads (SN ads) entertainment and consumers' attitude.

\section{Irritation}

Saxena and Khanna (2013) defined irritation as the feeling of discomfort that rises when consumers are viewing advertisement for personal or social reasons. Irritation was further perceived as a feeling of impatience which may increase into annoyance (Nwagwu \& Famiyesin, 2016). Ducoffe (1996) identified how consumers can be irritated by advertising they perceive as annoying, offensive or overly manipulative. Moreover, the increase in the amount of advertisements that consumers find on some sites, or ad clutter, can lead to irritation (Kim \& Sundar, 2010). Ducoffe, (1996); Wong and Tang (2008); and Saxena and 
Khanna (2013) proved that consumers develop unfavorable attitudes towards the product advertised when they feel that the advertisements are irritating or disturbing. However, in the case of Internet advertising, it was also found that advertisements are producing extensive irritation (Schlosser, Shavitt, \& Kanfer, 1999).Based on this rationale the following hypothesis will be examined:

H4: There is a significant negative association between Social Networks ads (SN ads) irritation and consumers' attitude.

\section{Materialism}

Richins and Dawson (1992) identified materialism as the belief that one's possessions is essential to the individual's happiness and social progress. Similarly, Ashikali and Dittmar (2012) noted that materialism embraces the desire for a lifestyle associated with image, fame and success, as well as an emphasis on possessions.

On the other hand, Park, Burns, and Rabolt, (2007) found a causal relationship between materialism and consumer' attitudes and behaviors towards online purchases. Similarly, Chang and Zhang (2008) found materialism as a determinant of consumers' attitude towards online gaming. Hence, the researchers propose the following hypothesis:

H5: There is a significant positive relationship between Social Networks ads (SN ads) materialism and consumers' attitude.

\section{Peer Influence}

Jung, Shim, Jin, and Khang, (2016) indicated that SNS users are impacted by content sent by peers. The findings of their study 
demonstrated that peer influence had the most significant impact on attitude and behavioural intention across all types of SNS.

Moreover, Wais and Clemons (2008) found that respondents favor to receive promotional messaging (advertisements) from another person rather than the advertiser and would likely have a positive perception of such promotional messaging. Therefore, the following hypothesis is insinuated:

H6: There is a significant positive relationship between Social Networks ads ( $\mathrm{SN}$ ads) peer influence and consumers' attitude.

\section{Attitude towards Online Advertising, Intention and Actual Purchase Relationship}

The concepts of attitude, intention and behavior constitute the three principles of the Theory of Reasoned action developed by Fishbein and Ajzen (1975); they stated that behavioral intention is an indication of an individual's readiness to perform a given behavior. In their study, they discussed how attitude affects behavior through intention. Following, Ajzen (1991) defined attitude as an individual's favourable or unfavourable assessment with using a particular service. Eagly and Chaiken (1993) viewed attitude as an assessment to particular object with some extent of favour or disfavor. Alternatively, attitude towards an advertisement is the consumers' feeling regarding a specific message either positively or negatively. Mei, Ling and Piew (2012) stated that attitude shows how the degree to which the person appreciates the performance of specific behaviour. Tang and Chan (2017) also concluded that consumers' attitudes will lead to stronger purchase intention.

Troudi and Bouyoucef (2020) applied the Theory of Reasoned action and concluded the evidence of a positive relationship between attitude and intention. Several studies have provided 
empirical findings on the positive relationship between attitude and behavioral intention in advertising, for example Tsang, Ho \& Liang (2004).

In addition, (Mittal, 1994) included perceptions of consumers towards advertising as a source of pleasure/hedonic, and as a source of product information and social role. The previous factors can have a positive effect on the general attitudes toward advertising that could stimulate purchasing decisions. Moreover, (Mehta, 2000) concluded how consumers' attitudes towards advertising are significant factors in determining advertising effectiveness.

In a comparative study between Romanian and Bulgarian consumers, Petrovici and Marinov (2007) found that, as opposed to their Bulgarian counterparts, Romanian consumers have favorable opinions toward advertising, and that they perceive it as informative, entertaining and fulfilling a social role. Yet, product information acquisition was the main use of advertising, which influences Bulgarian's consumers' attitude towards ads.

It is important to note that attitudes towards advertising are different according to the medium used. For example, print ads are perceived as more informative and enjoyable than broadcast ones, while television and radio advertisements are rated more aggressive and annoying than print ads (Somasundaran \& Light, 1991). Furthermore, Voorveld and van Noort (2014) agreed that media type has an influence on the behavioural response of consumers. They concluded that using social network sites with television in ad campaigns produces more favorable response than using these media individually.

Further, Eagly and Chaiken (1993) defined intention as a person's mindful set as to put forth an effort to carry out behaviour. In addition, Salisbury, Pearson, Pearson, and Miller (2001) indicated that online purchase intention affects positivity online purchasing. $\mathrm{Xu}, \mathrm{Oh}$ and Teo (2009) found that attitude was a significant predictor for purchase intention. Moreover, Leung, Bai, \& Stahura, (2015) concluded that a favorable 
attitude towards the Facebook page increased the consumers' intention-to-purchase. Yang (2012) stated that advertising messages provided by Facebook increases consumers' attitudes towards brand and purchase intentions. Mehta (2000) revealed that users, who show positive attitudes towards advertising, are more convinced by its content.

Academic researchers have considered that purchase intention leads to purchase behaviour (Armstrong et al., 2000). There is a strong assumption that intentions are indicators of purchase behaviours. This is obvious and proved in a number of models, which measured the attitude, intention, and behaviour relationships (Bazoche et al., 2008). Specifically, studies in advertising have noted the relationship between intention and behaviour. According to Cho \& Cheon (2004), consumer behaviour in a marketing campaign indicates the degree to which an individual could be engaged in an exchange with the advertiser whether positively or negatively.

Grounded on the above literature, the researchers propose the following:

H7: There is a significant positive relationship between consumers' attitude towards SN ads and their purchase intention.

H8: There is a significant positive relationship between consumers' intention to purchase from $\mathrm{SN}$ ads and their actual purchase.

Figure 1 here-under illustrates the research conceptual framework. 


\section{RESEARCH METHODOLOGY Sample and Data Collection}

To achieve the current research objectives, an extensive literature review was conducted.

The research population was identified as any Egyptian whose intention and / or actual purchase decision is affected by Social Network Sites advertisements (SN ads). A structured questionnaire was developed and uploaded on Google forms using the following link https://docs.google.com/forms/d/e/1FAIpQLScYPwTSHKGLm8Fvig5 jC4GVXWP7eWs3T7TiupZm0_AhOS1bwQ/viewform?usp=sf_link. Seventy-three (73) respondents completed the online questionnaire. To improve the response rate, the researchers collected additional data from a convenience sample, where most of the respondents were undergraduate and postgraduate students from one of the largest public universities, and a private one located in greater Cairo the capital of Egypt. University students were perceived as valid representation of the Egyptian population as the total number of students in the chosen universities from which the sample was drawn accounts for 10.2 percent of the overall number of students enrolled in all the Egyptian public and private universities (Daily News Egypt, 2019). In addition, using students' sample is in consistent with past studies (Wong et al., 2015; Teo et al., 2015; Tan et al., 2014).

302 respondents completed a self-administered questionnaire. Thus, the total research sample accounts for 375 respondents, of whom 39 per cent are males and 61 per cent are females. In terms of age, around 71 per cent are aged between 18 and 22 years, almost 13 per cent are aged 42 years and above, and the remaining 16 per cent are aged between 23 and less than 42 years. Facebook is the preferred SNS for nearly 62.5 per cent of the respondents, followed by Instagram with almost 25 per cent. In terms of length and frequency of SNS usage, almost 78 per cent of the respondents have an account on their preferred SNS for more than 2 years, and they log on to it several times a day. 
Figure 1: The Research Conceptual Framework

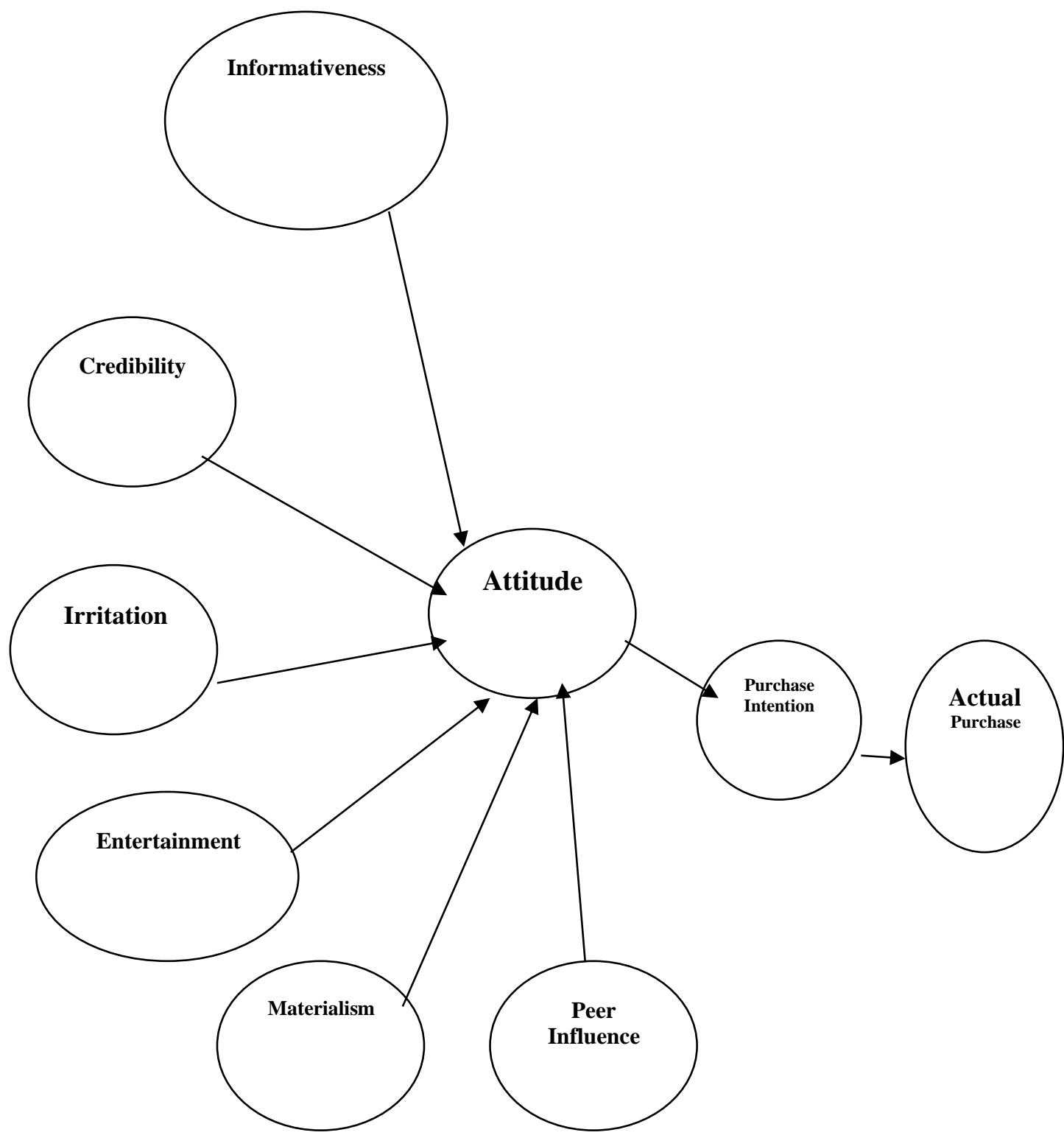




\section{Measurement Scales}

To measure the proposed concepts of the research, multi-item scales were used. The scales were sourced from relevant literature. All items used in the research instrument were measured on a 5-point Likert scale where $1=$ totally disagree and $5=$ totally agree.

The first section of the questionnaire focused on advertising value dimensions namely: informativeness, credibility, irritation; and entertainment. The scales were adapted from (Ducoffe, 1995, 1996; Taylor et al., 2011; Tsang et al., 2004; Brackett \& Carr, 2001). In addition, materialism and peer influence were adapted from (Taylor et al., 2011), as they were extensively underscored in the literature as antecedents to attitude towards SN ads. While, the second section focused on attitude towards SN ads that was adapted from Sun and Wang (2010). Further, the third section underlined intention to purchase and actual purchase scales that were adapted from (Mikalef et al., 2013; Tsang et al., 2004). Finally, the research instrument concluded with some demographic questions, as well as some multiplechoice questions that asked respondents about their most frequently used SNS, period and frequency of usage of their preferred SNS.

The questionnaire was pre-tested on 30 respondents not included in the final research sample. The aim was to examine its clarity, to modify any ambiguous questions, and to further improve the measurement scales used. The respondents' suggestions and recommendations were considered in the final version of the research instrument. 


\section{Data Analysis}

Statistical Package for Social Sciences (SPSS 25), as well as Analysis of Moment Structures (AMOS 24) were used to analyse the research data. The latter was chosen to measure the mediating effect of attitude towards $\mathrm{SN}$ ads and intention to purchase on the respondents actual purchase.

The data analysis was executed in two steps as follows: first, the validity and reliability of the measurement model were established, followed by the assessment of the structural model.

\section{Analysis of the Measurement Model}

Confirmatory Factor Analysis (CFA) was conducted to examine the validity and reliability of the measurement scales. CFA emphasized the need to remove some items from the research constructs due to their low standardized factor loading, which was below the minimum recommended cut-off point of 0.50 (Hair et al., 2010). The items removed were as follows: three items from SN ads informativeness, two items from SN ads credibility, three items from SNS ads irritation, one item from SNS ads entertainment, two items from SN ads materialism, three items from $\mathrm{SN}$ ads peer influence, two items from attitude towards SN ads, four items from intention to purchase from SN ads, and one item from actual purchase from SN ads. Table I summarizes CFA results, as well as the research statistics (e.g. CR; AVE). 
The effect of social $\ldots$ Dr Rasha H.A \& Dr. Madiha Metawie Accepted date 16/9/2020

\section{Table 1: Summary of Statistics}

\begin{tabular}{|c|c|c|c|c|c|}
\hline Items for each construct & $\begin{array}{c}\text { Factor } \\
\text { Loading }\end{array}$ & $t$-values & $\begin{array}{c}\text { Cronbach } \\
\text { Alpha }\end{array}$ & $\begin{array}{l}\text { Composite } \\
\text { Reliability }\end{array}$ & AVE \\
\hline $\begin{array}{l}\text { SN ads Informativeness } \\
\text { INF }\end{array}$ & & & 0.741 & 0.741 & 0.40 \\
\hline INF 1 & 0.644 & & & & \\
\hline INF 2 & 0.607 & 9.433 & & & \\
\hline INF 5 & 0.664 & 10.08 & & & \\
\hline INF 6 & 0.532 & 8.476 & & & \\
\hline INF 7 & 0.568 & 8.948 & & & \\
\hline SN ads Credibility CRD & & & 0.769 & 0.773 & 0.532 \\
\hline CRD 3 & 0.718 & & & & \\
\hline CRD 4 & 0.783 & 12.55 & & & \\
\hline CRD 5 & 0.684 & 11.43 & & & \\
\hline SN ads Irritation IRI & & & 0.73 & 0.755 & 0.510 \\
\hline IRI 2 & 0.634 & & & & \\
\hline IRI 4 & 0.84 & 10.62 & & & \\
\hline IRI 5 & 0.651 & 9.877 & & & \\
\hline $\begin{array}{l}\text { SN ads Entertainment } \\
\text { ENT }\end{array}$ & & & 0.883 & 0.886 & 0.661 \\
\hline ENT 2 & 0.694 & & & & \\
\hline ENT 3 & 0.813 & 14.40 & & & \\
\hline ENT 4 & 0.839 & 14.82 & & & \\
\hline ENT 5 & 0.893 & 15.55 & & & \\
\hline SN ads Materialism MAS & & & 0.723 & 0.740 & 0.593 \\
\hline MAT 2 & 0.878 & & & & \\
\hline MAT 3 & 0.644 & 6.007 & & & \\
\hline SN ads Peer Influence PI & & & 0.836 & 0.853 & 0.669 \\
\hline PI 4 & 0.940 & & & & \\
\hline PI 5 & 0.899 & 19.40 & & & \\
\hline PI 6 & 0.561 & 11.60 & & & \\
\hline $\begin{array}{l}\text { Attitude towards SN ads } \\
\text { ATT }\end{array}$ & & & 0.756 & 0.771 & 0.539 \\
\hline ATT 1 & 0.756 & & & & \\
\hline ATT 4 & 0.519 & 9.636 & & & \\
\hline ATT 5 & 0.881 & 16.21 & & & \\
\hline Intention to purchase IP & & & 0.709 & 0.71 & 0.550 \\
\hline IP 1 & 0.743 & & & & \\
\hline IP 6 & 0.740 & 13.35 & & & \\
\hline Actual Purchase AP & & & 0.69 & .70 & 0.534 \\
\hline AP 1 & 0.776 & & & & \\
\hline AP 2 & 0.683 & 13.47 & & & \\
\hline
\end{tabular}


All remaining items loaded successfully on a single factor with standardized loading greater than 0.50 (Anderson \& Gerbing, 1988), hence evidencing strong convergent validity. Additionally, CFA goodness-of-fit indices indicated satisfactory model fit were $\left(\mathrm{x}^{2}=492.23, \mathrm{df}=288, p=1.709\right)$, GFI $=0.915$, $\mathrm{AGFI}=0.888, \mathrm{CFI}=0.95 ; \mathrm{TLI}=0.94, \mathrm{NFI}=0.90, \mathrm{IFI}=0.95$, and RMSEA $=.04$. The results indicated that all fit indices either reached, or exceeded the benchmarks suggested in previous studies (Jackson et al., 2009; Kline, 2010).

Further, all composite reliability values and Cronbach's alpha coefficients were equal to, or exceeded 0.7, emphasizing a good level of internal consistency (Nunnally \& Bernstein, 1994; Bagozzi, 1994). In addition, convergent validity was established as the AVE values for all the constructs were equal or greater than 0.50 (Fornell \& Larcker, 1981; Bagozzi \& Yi, 1988), except for SN ads informativeness which is slightly below the cut-off point 0.5 (Table I). However, according to Fornell and Larcker (1981), the Average Variance Extracted (AVE) is a more conservative measure of convergent validity than construct reliability. Therefore, based on the values of $\mathrm{CR}$, it can be concluded that convergent validity of the construct is adequate. Accordingly, all research measures demonstrate convergent validity.

Finally, following Bagozzi and Yi (1988), all the constructs items were checked for normality using Skewness and Kurtosis tests. Table II shows the results where all the values fall within the acceptable range from -1.0 to +1.0 , thus providing support for normality.

Based on the above analysis, it was concluded that the research constructs have satisfactory and acceptable measurement properties to proceed with the analysis, and to evaluate the structural model. 
The effect of social $\ldots$ Dr Rasha H.A \& Dr. Madiha Metawie Accepted date 16/9/2020

Table 2: Descriptive Statistics and Normality Test for Research Constructs

\begin{tabular}{|c|c|c|c|c|}
\hline Items for each construct & Mean & $\begin{array}{c}\text { Std. } \\
\text { Deviation }\end{array}$ & Skewness & Kurtosis \\
\hline \multicolumn{5}{|l|}{$\begin{array}{l}\text { SN ads Informativeness } \\
\text { INF }\end{array}$} \\
\hline INF 1 & 3.67 & 1.036 & -0.720 & 0.123 \\
\hline INF 2 & 2.92 & 1.001 & 0.172 & -0.526 \\
\hline INF 5 & 3.45 & 0.900 & -0.475 & 0.014 \\
\hline INF 6 & 3.53 & 0.924 & -0.395 & -0.155 \\
\hline INF 7 & 3.63 & 0.880 & -0.710 & 0.632 \\
\hline \multicolumn{5}{|l|}{ SN ads Credibility CRD } \\
\hline CRD 3 & 2.95 & 0.885 & -0.035 & 0.054 \\
\hline CRD 4 & 2.67 & 0.855 & 0.001 & 0.254 \\
\hline CRD 5 & 2.96 & 0.836 & -0.233 & 0.579 \\
\hline \multicolumn{5}{|l|}{ SN ads Irritation IRI } \\
\hline IRI 2 & 2.55 & 1.159 & 0.303 & -0.829 \\
\hline IRI 4 & 2.82 & 1.011 & -0.016 & -0.450 \\
\hline IRI 5 & 2.84 & 0.926 & 0.038 & 0.085 \\
\hline \multicolumn{5}{|l|}{$\begin{array}{l}\text { SN ads Entertainment } \\
\text { ENT }\end{array}$} \\
\hline ENT 2 & 3.11 & 0.884 & -0.086 & 0.059 \\
\hline ENT 3 & 3.18 & 1.038 & -0.075 & -0.442 \\
\hline ENT 4 & 3.10 & 1.050 & 0.002 & -0.539 \\
\hline ENT 5 & 3.09 & 0.997 & 0.023 & -0.372 \\
\hline \multicolumn{5}{|l|}{ SN ads Materialism MAS } \\
\hline MAT 2 & 3.84 & 0.978 & -0.594 & -0.162 \\
\hline MAT 3 & 3.90 & 1.000 & -0.875 & 0.480 \\
\hline \multicolumn{5}{|l|}{ SN ads Peer Influence PI } \\
\hline PI 4 & 3.09 & 1.094 & -0.014 & -0.707 \\
\hline PI 5 & 3.15 & 1.131 & -0.146 & -0.851 \\
\hline PI 6 & 3.18 & 0.906 & -0.252 & 0.111 \\
\hline \multicolumn{5}{|l|}{$\begin{array}{l}\text { Attitude towards SN ads } \\
\text { ATT }\end{array}$} \\
\hline ATT 1 & 3.37 & 0.969 & -0.498 & -0.044 \\
\hline ATT 4 & 3.87 & 0.858 & -0.907 & 1.276 \\
\hline ATT 5 & 3.25 & 1.053 & -0.438 & -0.343 \\
\hline \multicolumn{5}{|l|}{ Intention to purchase IP } \\
\hline IP 1 & 3.30 & 0.888 & -0.330 & 0.194 \\
\hline IP 6 & 3.11 & 0.839 & -0.187 & 0.081 \\
\hline \multicolumn{5}{|l|}{ Actual Purchase AP } \\
\hline AP 1 & 3.15 & 0.872 & -0.251 & 0.036 \\
\hline AP 2 & 3.30 & 0.988 & -0.349 & -0.353 \\
\hline
\end{tabular}




\section{Analysis of the Structural Model}

Structural Equation Modelling (AMOS 24) was used to test the research hypotheses. The overall model fit was assessed using number of measures. Table III shows that Chi-square (x 2) value of 548.915 with 301 degrees of freedom is statistically insignificant $(p=1.824)$ at 0.05 level. The results further exhibit that all fit indices obtained are satisfactory and within the suggested boundaries as follows: $(\mathrm{GFI}=0.90 ; \mathrm{AGFI}=0.88$; $\mathrm{CFI}$ $=0.94 ; \mathrm{TLI}=0.93 ; \mathrm{RMSEA}=0.0 .04 ; \mathrm{RMR}=0.05 ; \mathrm{IFI}=0.94)$. Accordingly, the results confirm an acceptable fit of the proposed model.

\section{Table 3: Path Coefficients and Significances}

\begin{tabular}{|c|c|c|c|c|c|}
\hline HP & Structural Path & $\begin{array}{c}\text { Path } \\
\text { Coefficient }\end{array}$ & $t$-value & $p$ & $\begin{array}{c}\text { Acceptance / } \\
\text { Rejection }\end{array}$ \\
\hline HP 1 & SN ads INF $\longrightarrow$ ATT & 0.308 & 3.585 & $* * *$ & Accepted \\
\hline HP 2 & $\mathrm{SN}$ ads $\mathrm{CRD} \longrightarrow \mathrm{ATT}$ & 0.067 & 0.791 & $0.429^{\text {ns }}$ & Rejected \\
\hline HP 3 & SN ads IRI $\longrightarrow$ ATT & 0.162 & 2.803 & $0.005^{* *}$ & Accepted \\
\hline HP 4 & $\mathrm{SN}$ ads ENT $\longrightarrow \mathrm{ATT}$ & 0.432 & 6.867 & $* * *$ & Accepted \\
\hline HP 5 & SN ads MAT $\longrightarrow$ ATT & 0.134 & 2.565 & $0.01 * *$ & Accepted \\
\hline HP 6 & $\mathrm{SN}$ ads $\mathrm{PI} \longrightarrow \mathrm{ATT}$ & 0.089 & 2.042 & $0.041 *$ & Accepted \\
\hline HP 7 & ATT towards SNS ads $\longrightarrow$ IP & 0.739 & 10.698 & $* * *$ & Accepted \\
\hline HP 8 & $\mathrm{IP} \longrightarrow \mathrm{AP}$ & 1.05 & 13.709 & $* * *$ & Accepted \\
\hline \multicolumn{6}{|c|}{ 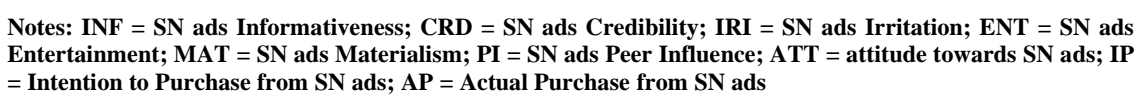 } \\
\hline
\end{tabular}

Table III and Figure 2 illustrate the path coefficients of the overall model. The results provide support to all research hypotheses, except for $\mathrm{H} 2$. The structural model indicates that 
SN ads informativeness, irritation, entertainment, materialism and peer influence have significant positive association with attitude towards $\mathrm{SN}$ ads. While the relationship with $\mathrm{SN}$ ads credibility is insignificant. According to beta levels, SN ads entertainment has the strongest impact on attitude, followed by informativeness, then irritation, materialism and peer influence respectively. In addition, attitude towards $\mathrm{SN}$ ads has strong significant positive association with intention to purchase. Furthermore, intention to purchase from SN ads has significant positive association with actual purchase. Therefore, out of 8 proposed hypotheses, 7 were supported.

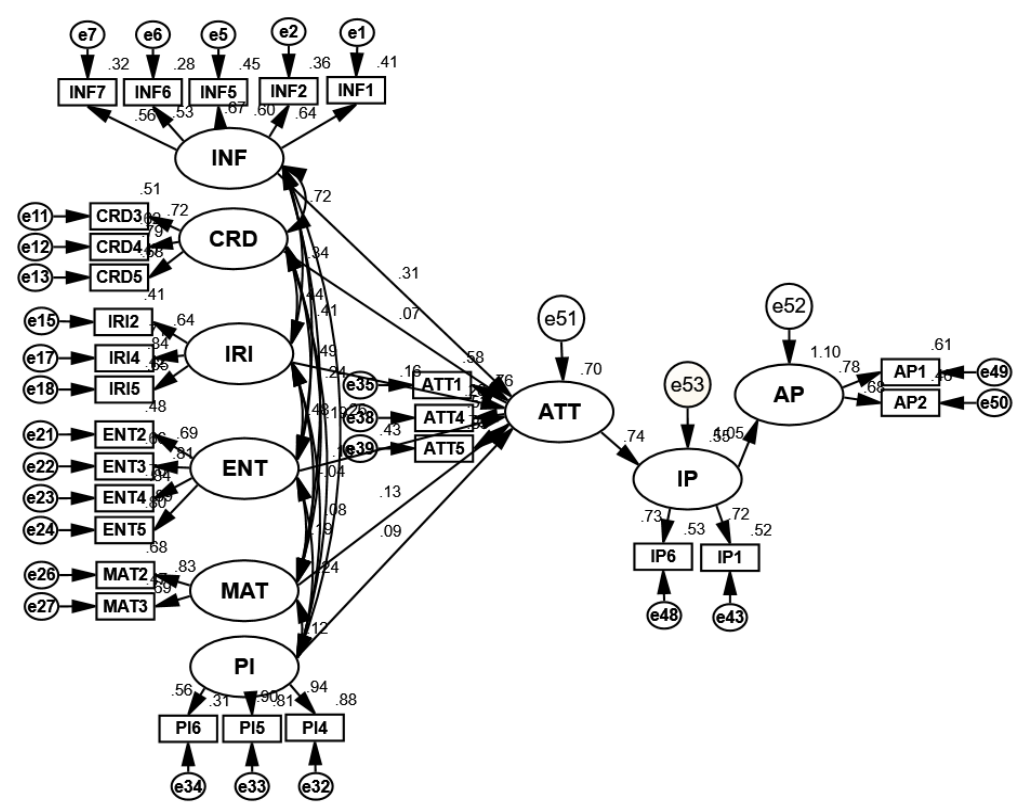

Figure 2: The Structural Model 
The researchers further examined the mediation (i.e. indirect) effect of attitude, and total effects of the research constructs on the intention to purchase, and the actual purchase from $\mathrm{SN}$ ads as illustrated in Table IV.

Table 4: The Indirect and Total Effects on Intention to purchase from SN ads and Actual Purchase

\begin{tabular}{|c|c|c|c|}
\hline Path & $\begin{array}{l}\text { Indirect } \\
\text { Effect }\end{array}$ & Path & $\begin{array}{l}\text { Total } \\
\text { Effect }\end{array}$ \\
\hline $\begin{array}{l}\mathrm{SN} \text { ads INF } \longrightarrow \mathrm{ATT} \longrightarrow \\
\mathrm{IP}\end{array}$ & $0.227 * * *$ & $\begin{array}{l}\mathrm{SN} \text { ads } \mathrm{INF} \longrightarrow \mathrm{ATT} \longrightarrow \mathrm{IP} \longrightarrow \\
\mathrm{AP}\end{array}$ & $0.239 * *$ \\
\hline $\begin{array}{l}\mathrm{SN} \text { ads } \mathrm{CRD} \longrightarrow \mathrm{ATT} \longrightarrow \\
\mathrm{IP}\end{array}$ & $0.049^{\mathrm{ns}}$ & $\begin{array}{l}\mathrm{SN} \text { ads } \mathrm{CRD} \longrightarrow \mathrm{ATT} \longrightarrow \mathrm{IP} \longrightarrow \\
\mathrm{AP}\end{array}$ & $0.052^{\mathrm{ns}}$ \\
\hline $\begin{array}{l}\mathrm{SN} \text { ads IRI } \longrightarrow \text { ATT } \\
\mathrm{IP}\end{array}$ & $0.12 *$ & $\begin{array}{l}\mathrm{SN} \text { ads IRI } \longrightarrow \mathrm{ATT} \longrightarrow \mathrm{IP} \longrightarrow \\
\mathrm{AP}\end{array}$ & $0.126^{*}$ \\
\hline $\begin{array}{l}\mathrm{SN} \text { ads } \mathrm{ENT} \longrightarrow \mathrm{ATT}- \\
\mathrm{IP}\end{array}$ & $0.319 * * *$ & $\begin{array}{l}\mathrm{SN} \text { ads } \mathrm{ENT} \longrightarrow \mathrm{ATT} \longrightarrow \mathrm{IP} \longrightarrow \\
\mathrm{AP}\end{array}$ & $0.335 * * *$ \\
\hline $\begin{array}{l}\mathrm{SN} \text { ads } \mathrm{MAT} \longrightarrow \mathrm{ATT}- \\
\mathrm{IP}\end{array}$ & $0.099 * *$ & $\begin{array}{l}\mathrm{SN} \text { ads } \mathrm{MAT} \longrightarrow \mathrm{ATT} \rightarrow \mathrm{IP} \longrightarrow \\
\mathrm{AP}\end{array}$ & $0.104 * *$ \\
\hline $\mathrm{PI} \longrightarrow \mathrm{ATT} \longrightarrow \mathrm{IP}$ & $0.066^{* *}$ & $\begin{array}{l}\mathrm{SN} \text { ads } \mathrm{Pr} \\
\mathrm{AP}\end{array}$ & $0.069 * *$ \\
\hline & & $\mathrm{ATT} \longrightarrow \mathrm{IP} \longrightarrow \mathrm{AP}$ & $0.775 * *$ \\
\hline
\end{tabular}

Notes: $\mathrm{INF}=\mathrm{SN}$ ads Informativeness; $\mathrm{CRD}=\mathrm{SN}$ ads Credibility; IRI $=\mathrm{SN}$ ads Irritation; $\mathrm{ENT}=\mathrm{SN}$ ads Entertainment $;$ MAT $=$ SN ads Materialism; PI $=$ SN ads Peer Influence; ATT $=$ attitude towards SN ads; IP= Intention to Purchase from SNS ads; AP = Actual Purchase from SN ads

Notes : ${ }^{*} p=0.1 ; * * p=0.05 ; * * * p=0.01 ; \mathrm{ns}=$ insignifiant

The results highlighted in Table IV above indicate the mediating effect of attitude on the relationship between SN ads informativeness, irritation, entertainment, materialism, and peer influence on one hand, and intention to purchase from SN ads on the other hand. In addition, the results underscore the total effects of both attitude towards SN ads and intention to purchase on the relationship between SN ads informativeness, irritation, entertainment, materialism, and peer influence on one hand, and 
actual purchase on the other hand. Meanwhile, the mediation and the total effects of attitude and attitude-intention respectively on the relation between $\mathrm{SN}$ ads credibility and actual purchase were not evident.

\section{DISCUSSION AND CONCLUSIONS}

The current research aimed to investigate the validity of Ducoffe (1996) Advertising Value model in the context of social networks among Egyptian consumers. The researchers further examined the inclusion of materialism and peer influence as antecedents to consumers' attitude towards SN ads. The research generated significant understandings of concepts related to advertising value, which is important for both academicians and advertisers. Structural Equation Modelling (SEM) was used to estimate the series of interrelated relationship among the research variables simultaneously. SEM results indicate the goodness of fit of the proposed model. Moreover, all the research hypotheses were statistically supported, except for the association between $\mathrm{SN}$ ads credibility and attitude.

The research results confirm the positive association between SN ads entertainment and consumers' attitude. Where entertainment came as the main antecedent of Egyptian consumers' favorable attitude towards $\mathrm{SN}$ ads. The result implies that $\mathrm{SN}$ ads provide Egyptian consumers with sense of pleasure and enjoyment. This conclusion is in line with Taylor et al. (2011), Wong and Tang (2008), Unal et al. (2011), and Jung et al. (2016) who asserted that entertainment is a significant predictor of consumers' attitude towards SN ads.

In addition, the findings suggest that the positive effect of attitude towards SN ads among Egyptian consumers depends on the ads ability to provide useful information. This implies that organizations should focus on the quality of information provided on $\mathrm{SN}$ ads, as such it should be up to date updated, 
timely and relevant. Hence, satisfying consumers need for information regarding specific products. It is of interest to note that this result is in consonance with several authors (e.g. Saxena \& Khanna, 2013; Mukherjee \& Banerjee, 2017; Duffet, 2015; Murillo et al., 2016; Yang et al., 2017).

Furthermore, the current research reveals positive association between $\mathrm{SN}$ ads materialism and consumers attitude. This means that Egyptian consumers put a lot of emphasis on possessions, and a lifestyle characterized by image and fame. Additionally, the findings are in consonance with the literature (e.g. Park et.al. 2007; Chang \& Zhang, 2008). Meanwhile, they contradict Boateng and Okoe (2015) result who report a negative relationship between materialism and attitude. Such contradiction emphasizes the Egyptian culture, and consumers' characteristics that play key roles in determining their favor of material possessions.

Likewise, the study reveals that Egyptian consumers positive attitude towards $\mathrm{SN}$ ads is influenced by their peers. The result agrees with Jung et al., (2016) who showed that peer influence had the most significant impact on attitude and behavioral intention across all types of social networks. The result also indicates the positive effect of social influence on consumers' attitude towards $\mathrm{SN}$ ads, where consumers note that they prefer receiving promotional messaging from other counterparts instead of the advertiser (Wais \& Clemons, 2008). This indicates that consumers are more likely to adopt same attitude towards SN ads as their peers.

Unlike the literature (e.g. Kim \& Sundar, 2010; Ducoffe, 1996; Saxena \& Khanna, 2013), the current research uncovers a positive association between $\mathrm{SN}$ ads irritation and consumers attitude. This implies that consumers do not feel annoyed and disturbed when they receive $\mathrm{SN}$ ads, accordingly they develop 
favorable attitude towards the product/service being advertised. In turn, it is recommended that advertisers should increase their usage of social networks as an advertising medium

Contrary to the mainstream result highlighted in the literature (e.g. Boateng \& Okoe, 2015; Murillo et al., 2016; Mukherjee \& Banerjee, 2017; Yang et. Al., 2017), the existing study reports insignificant effect of SN ads credibility on Egyptian consumers attitude. Such result could be interpreted in light of Egyptian consumers' personal characteristics, and type of product/service being advertised.

In addition, the results indicate that Egyptian consumers, in general, have favourable attitude towards $\mathrm{SN}$ ads, which in turn positively affect their intention to purchase the advertised product/service. This suggests that when the content of SN ad is attractive and relevant consumers will pay attention to it. Furthermore, it was found that consumers' intention to purchase from $\mathrm{SN}$ ad has significant positive association with their actual purchase. This result could be explained by the fact that $\mathrm{SN}$ ads include various interactive methods, which facilitate communication and interaction with customers. Therefore, with the continuous exposure to these sites, consumers develop favorable attitudes towards the ads, then show their intent and willingness to purchase the advertised product/brand. Ha and Janda (2014) proposed that positive attitudes influenced online behavioral intentions. In addition, Wolin et al. (2002) suggested that a favorable attitude towards online advertising resulted in repeated online purchasing. However, Maxwell (2013) showed that many consumers check products through different platforms but favor purchase from physical stores.

Overall, the research findings are in consonance with number of authors (e.g. Duffett, 2015; Yang et.al., 2017; Mukherjee \& Banerjee, 2017; Boateng \& Okoe, 2015). Hence, the results are 
giving support to the Theory of Reasoned Action in the Egyptian context.

\section{MANAGERIAL IMPLICATIONS}

The results of the present study have important managerial implications as follows. Marketers should give significant attention to the entertainment aspect of the ad. The more entertaining the ad will be the more likelihood that it will stimulate the consumers to continue watching it without clicking "skip ad" button. In addition, practitioners should provide SN users with informative, rich, relevant and up to date ads in order to obtain favorable attitude towards their product/brand. Yet, information without entertainment is useless.

Another managerial implication is concerned with the positive effect of SN ads irritation on consumers' attitude that reveals that the Egyptian consumers don't perceive SN ads as nagging or annoying. On the contrary, as long as the ads are entertaining, consumers don't mind being exposed to them. Thus, practitioners should consider advertise their product/brand on social networks besides traditional media tools. Accordingly, they should allocate considerable part of their promotional budget to $\mathrm{SN}$ ads.

Finally, practitioners should examine and analyze their consumers' profiles carefully and accurately to emphasize the desire of possession and acquisition of a product/brand in their ads. In addition, humans are social creatures by nature, thus the influence of friends, colleagues, and or partners should be highly considered and stressed upon in the ads. 


\section{LIMITATIONS AND DIRECTIONS FOR FUTURE RESEARCH}

The present study examined the interrelated relationships between entertainment, informativeness, irritation and credibility, as well as peer influence and materialism on Egyptian consumers' attitudes towards SN ads. However, the impact of other variables such as electronic word of mouth, corporate reputation, and consumer's personal characteristics can be studied in the future. The study did not differentiate between the various types of social networks, despite that most respondents chose Facebook as their most frequently used social network. Therefore, it is suggested that further research should be conducted to determine whether there is a difference in attitudinal effectiveness between various social network sites such as YouTube, Google+, LinkedIn and Twitter, as well as traditional media.

Future research could also undertake comparative studies between other countries, since developed countries might differ from developing ones. In addition, further investigation could be conducted to compare attitude and intention across genders, different age brackets, and different types of product/service.

\section{REFERENCES}

1. Ajzen, I. (1991). The theory of planned behavior. Organizational behavior and human decision processes, 50(2), 179-211.

2. Alenezi, Khalid Abdulkareem, Al Shaikhli, Imad Fakhri Taha, AlDabbagh, Sufyan Salim Mahmood and Alhatem, Khaled. (2017). The Influence of Internet and Social Media on Purchasing Decisions in Egypt and a Comparison between Egypt and Kuwait International. Journal of Computer Applications (0975 - 8887), 178 (5), 26-32. 
3. Altuna, Oylum Korkut, and Konuk, Faruk Anıl. (2009). Understanding Consumer Attitudes toward Mobile Advertising and Its Impact on Consumers' Behavioral Intentions: A CrossMarket Comprasion of United States and Turkish Consumers. International Journal of Mobile Marketing, 4(2), 43-51.

4. Anderson, J. and Gerbing, D. (1988), Structural equation modelling in practice: a review and recommended two-step approach. Psychological Bulletin, 103(3), 411-423.

5. Armstrong, J.S., Morwitz, V.G. and Kumar, V. (2000). Sales forecasts for existing consumer products and services: do purchase intentions contribute to accuracy? International Journal of Forecasting, 16(3), 383-397.

6. Ashikali, E.M., \& Dittmar, H. (2012). The effect of priming materialism on women's responses to thin-ideal media. British Journal of Social Psychology, 51(4), 514-533.

7. Bagozzi, R.P. (1994). The effects of arousal on the organization of positive and negative affect and cognitions: application to attitude theory. Structural Equation Modeling, 1 (3), 222-252.

8. Bazoche, P., Deola, C. and Soler, L. (2008). An experimental study of wine consumers' willingness to pay for environmental characteristics, paper presented at the 12th Congress of the European Association of Agriculture Economists, Retrieved from: www.legrenelleenvironment.fr/grenelle-environment

9. Boateng, H. and Okoe, F. (2015). Consumers' attitude towards social media advertising and their behavioural response: The moderating role of corporate reputation. Journal of Research in Interactive Marketing, 9(4), 299-312.

10. Brackett, L.K., \& Carr, B.N. (2001). Cyberspaces advertising vs. other media: Consumer vs. mature student attitudes. Journal of Advertising Research, 41(5), 23-32.

11. Chang, J.H., \& Zhang, H. (2008). Analyzing online game players: From materialism and motivation to attitude. Cyber Psychology \& Behavior, 11(6), 711-714. 
12. Cheung Christy M.K. \& Lee Matthew K.O. (2010). A theoretical model of intentional social action in online social networks. Decision support system. 49(1), 24-30.

13. Cho, C.H. and Cheon, H.J. (2004). Why do people avoid advertising on the internet?. Journal of Advertising, 53(4) 89-97.

14. Doney, P. and Cannon, J. (1997). An Examination of the Nature of Trust in Buyer-Seller Relationships, Journal of Marketing, 61(2), pp. 35-51.

15. Ducoffe, R. H. (1996). Advertising Value and advertising on the web. Journal of Advertising Research, 36(1), 21-36.

16. Ducoffe, R.H. (1995). How consumers assess the value of advertising. Journal of Current Issues \& Research in Advertising, 17(1), 1-18.

17. Duffett, Rodney Graeme, (2015). Facebook advertising's influence on intention-to-purchase and purchase amongst Millennials. Internet Research, 25(4), 498-526.

18. Durvasula, S., Lysonski, S. and Watson, J. (2001).Does vanity describe other cultures? A cross-cultural examination of the vanity scale. Journal of Consumer Affairs, 35(1), 180-199.

19. Eagly, A.H. and Chaiken, S. (1993). The Psychology of Attitudes. Fort Worth, TX: Harcourt Brace Jovanovich.

20. Faraz, S. and Hamid, K.H. (2010). Mobile advertising: an investigation of factors creating positive attitude in Iranian customers. African Journal of Business Management, 5(2), 394404.

21. Fishbein, M., and I. Ajzen. (1975). Beliefs, attitudes, intention, and behavior: An introduction to theory and research. Reading, MA: Addison Wesley.

22. Fornell, C. and Larcker, D.F. (1981), Evaluating structural equation models with unobservable variables and measurement error, Journal of Marketing Research, 18(1), 3980.

23. Gao, Y. and Koufaris, M. (2006). Perceptual antecedents of users attitude in electronic commerce. ACM SIGMIS Database, 37(2/3), 42-50. 
24. Ha, H. and Janda, S. (2014). The effect of customized information on online purchase intentions. Internet Research, 24(4) 124-165.

25. Hair, J.F., Black, W.C., Babin, B.J. and Anderson, R.E. (2010). Multivariate Data Analysis, (7th edition). Upper Saddle River, NJ Prentice Hall.

26. https://www.emarketer.com/content/global-digital-adspending-2019

27. https://wwww.dailynewssegypt.com/2019/11/17/studentenrolment-in-higher-education-increase-by-4-during-2018-2019capmas. Accessed on 31 May 2020

28. Interactive Advertising Bureau. (2009). Social advertising best practices. New York.

29. Jackson, D.L., Gillaspy, J.A. and Purc-Stephenson, R. (2009). Reporting practices in confirmatory factor analysis: an overview and some recommendations. Psychological Methods, 14(1), 6-23.

30. Jung, Jaemin, Shim, Sung Wook, Jin, Hyun Seung \& Khang, Hyoungkoo. (2016). Factors affecting attitudes and behavioural intention towards social networking advertising: a case of Facebook users in South Korea. International Journal of Advertising 35(2), 248-265.

31. Kaplan AM, \& Heanlein M, (2010). Users of the world unite: The challenges and opportunities of social media. Business Horizons, 53(1), 59-68.

32. Kim, M., \& Lee, M. (2010). Why do college students use Twitter? Presented at the Association for Education in Journalism and Mass Communication Annual Conference, 4-7 August 2007, Denver, CO.

33. Kim, N. Y., \& Sundar, S. S. (2010). Relevance to the rescue: Can Smart Ads reduce negative response to online ad clutter?. Journalism \& Mass Communication Quarterly, 87(2), 346-362. 
34. Kline, R.B. (2010). Principles and Practice of Structural Equation Modeling (3rd ed.). New York, NY, The Guilford Press.

35. Lenhart, A., Purcell, K., Smith, A. and Zickuhr, K. (2010). Social media and young adults, Pew Internet \& American Life Project, Retrieved from: www.pewinternet.org/,/media//Files/

Reports/2010/PIP_Social_Media_and_Young_Adults_Report_Fi nal_with_toplines.pd

36. Leung, X.Y., Bai, B. and Stahura, K.A. (2015). The marketing effectiveness of social media in the hotel industry: a comparison of Facebook and Twitter. Journal of Hospitality \& Tourism Research, 39(2), 147-169.

37. Logan, Kelty, Bright, Laura F., Gangadharbatla, Harsha, (2012). Facebook versus television: advertising value perceptions among females. Journal of Research in Interactive Marketing, 6(3),164-179.

38. Maxwell, J. (2013). Demystifying the online shopper 10 myths of multichannel retailing. PWC's Multichannel Retail Survey, 3-35.

39. McCarthy, J., Rowley, J., Ashworth, C.J. and Pioch, E. (2014). Managing brand presence through social media: the case of UK football clubs. Internet Research, 24(2), 181-204.

40. McQuail, D. (1994). Mass communication theory: An introduction. London, UK: SAGE.

41. Mehta, A. (2000). Advertising attitudes and advertising effectiveness. Journal of Advertising Research, 40(3), 67-71.

42. Mei, O.J., Ling, K.C. and Piew, T.H. (2012). The antecedents of green purchase intention among Malaysian consumers. Asian Social Science, 8(13), 248-263.

43. Mikalef, P., Giannakos, M., \& Pateli, A. (2013). Shopping and word-of-mouth intentions on social media. Journal of Theoretical and Applied Electronic Commerce Research, 8(1), 17-34. 
44. Mittal, B. (1994). Public assessment of TV advertising: faint praise or harsh criticism. Journal of Advertising Research, 40(3), 35-53.

45. Moore, J.J., \& Rodgers, S.L. (2005). An examination of advertising credibility and skepticism in five different media using the persuasion knowledge model. In Proceedings of the Conference-American Academy of Advertising 2005, 10. Pullman, WA; American Academy of Advertising.

46. Mukherjee, K. and Banerjee, N. (2017). Effect of Social Networking Advertisements on Shaping Consumers' Attitude. Global Business Review, 18(5), 1291-1306.

47. Murillo, E. Merino, M. and Nunez, A. (2016). The advertising value of Twitter Ads: a study among Mexican Millennials. Review of Business Management, 18(61), 436-456.

48. Nielsen (2010). Advertising effectiveness: Understanding the value of a social media impression. New York: The Nielsen Company.

49. Nunnally, J.C. and Bernstein, I.H. (1994). Psychometric Theory (3rd ed.), New York, NY, McGraw-Hill.

50. Nwagwu, Williams, Ezinwa, and Famiyesin, Bunmi. (2016). Acceptance of mobile advertising by consumers in public service institutions in Lagos, Nigeria. The Electronic Library, 34(2), 265-288.

51. Park, H.J., Burns, L.D., \& Rabolt, N.J. (2007). Fashion innovativeness, materialism, and attitude toward purchasing foreign fashion goods online across national borders: The moderating effect of internet innovativeness. Journal of Fashion Marketing and Management, 11(2), 201-214.

52. Patino, A., Pitta, D.A. and Quinones, R. (2012). Social media's emerging importance in market research. Journal of Consumer Marketing, 29(3), 233-237.

53. Petrovici, Dan and Marinov, Marin (2007). Determinants and antecedents of general attitudes towards advertising, A study of two EU accession countries. European Journal of Marketing, 41(3/4), 307-326. 
54. Richins, M.L., \& Dawson, S. (1992). A consumer values orientation for materialism and its measurement: Scale development and validation. Journal of Consumer Research, 19(3), 303-316.

55. Salisbury, W.D., Pearson, R.A., Pearson, A.W., \& Miller, D.W. (2001). Perceived security and worldwide web purchase intention. Industrial Management \& Data Systems, 101(4), 165177. Retrieved from http://dx.doi. org/10.1108/02635570110390071.

56. Saxena, A., \& Khanna, U. (2013). Advertising on social network sites: A structural equation modelling approach. Vision: The Journal of Business Perspective, 17(1), 17- 25.

57. Schlosser, A.E., Shavitt, S., \& Kanfer, A. (1999). Survey of Internet users' attitudes toward Internet advertising. Journal of interactive marketing, 13(3), 34-54.

58. Soh, Hyeonjin, Reid, Leonard N., and king, Karen Whitehill, (2007). Trust in Different Advertising Media. Journalism of Mass Communication Quarterly, 84(3), 455-476.

59. Somasundaran, T.N and Light, C. David, (1991). CrossCultural and Media Specific Analysis of Student Attitudes toward Advertising, Proceedings of the American Marketing Associations, Educator's Conference, 2, ed.

60. Sun, S. and Wang, Y. (2010). Examining the role of beliefs and attitudes in online advertising: a comparison between the USA and Romania. International Marketing Review, 27(1), 87-107.

61. Tan, G. W. H., Ooi, K. B., Leong, L. Y., \& Lin, B. (2014). Predicting the drivers of behavioral intention to use mobile learning: A hybrid SEM-Neural Networks approach. Computers in Human Behavior, 36, 198-213.

62. Tang, Mui Joo and Chan, Eang Teng. (2017). The Impact of Online Advertising on Generation Y's Purchase Decision in Malaysia. World Academy of Science, Engineering and Technology, International Journal of Humanities and Social Sciences, 11(4), 964-972. 
63. Taylor, D.G., Lewin, J.E., \& Strutton, D. (2011). Friends, fans, and followers: Do ads work on social networks? How gender and age shape receptivity. Journal of Advertising Research, 51(1), 258-275.

64. Teo, A. C., Tan, G. W. H., Ooi, K. B., \& Lin, B. (2015). Why consumers adopt mobile payment? A partial least squares structural equation modelling PLS-SEM approach. International Journal of Mobile Communications, 13(5), 478-497.

65. Troudi, Hadjer and Bouyoucef, Djamila. (2020), Predicting purchasing behaviour of green food in Algerian context. EuroMed Journal of Business, 15(1), 1-21.

66. Trusov, M., Bucklin, R.E., \& Pauwels, K. (2009). Effects of word-of-mouth versus traditional marketing: Findings from an Internet social networking site. Journal of Marketing, 73(5), 90102.

67. Tsang, Melody M., Ho, Shu-Chun. And Liang, TingPeng. (2004). Consumer Attitudes Toward Mobile Advertising: An Empirical Study, International Journal of Electronic Commerce, 8(3), 65-78.

68. Ünal, S. Aysel, E. and Keser, E. (2011). Attitudes towards Mobile Advertising - A Research to Determine the Differences between the Attitudes of Youth and Adults. Procedia Social and Behavioral Sciences, 24, 361-377.

69. Voorveld, H.A., \& van Noort, G. (2014). Social media in advertising campaigns examining the effects on perceived persuasive intent, campaign and brand responses. Journal of Creative Communications, 9(3), 253-268.

70. Wais, J.S., and E.K. Clemons. (2008). Understanding and implementing mobile social advertising. International Journal of Mobile Marketing, 3(1), 12-9.

71. Wang, Y and Sun, S. (2010). Assessing Beliefs, Attitudes and Behavioral Responses Toward Online Advertising in Three Countries. International Business Review, 19(4), 333-344. 
72. Wang, Y. Sun, S. Lei, W. and Toncar, M. (2009). Examining beliefs and attitudes toward online advertising among Chinese consumers. Direct Marketing: An International Journal, 3(1), 52-66.

73. Wolin, L.D., Korgaonkar, P. and Lund, D. (2002), Beliefs, attitudes and behaviour towards web advertising. International Journal of Advertising, 21(1), 87-113.

74. Wong, C. H., Tan, G. W. H., Tan, B. I., \& Ooi, K. B. (2015). Mobile advertising: the changing landscape of the advertising industry. Telematics and Informatics, 32(4), 720734.

75. Wong, T. and Tang, Y. (2008). Consumers' Attitudes Towards Mobile Advertising: The Role of Permission, Review of Business Research, 8(3), 181-187.

76. Wongman, T.M. (2010). Attitude towards mobile advertising. (Master's thesis). Department of Management and Marketing, The Hong Kong Polytechnic University, Hong Kong.

77. Xu, H., Oh, Lih-Bin, \& Teo, H. (2009). Perceived effectiveness of text vs. multimedia location-based advertising messaging. International Journal of Mobile Communications, $7(2), \quad 154-177 . \quad$ Retrieved from http://dx.doi. org/10.1504/IJMC.2009.022440.

78. Yang, K. Huang, C. Yang, C. and Yang, S. (2017). Consumer attitudes toward online video advertisement: YouTube as a platform. Kybernetes, 46(5), 840-853.

79. Yang, T. (2012). The decision behaviour of Facebook users. Journal of Computer Information Systems, 52(3), 50-59.

80. Zha, X., Li, J., \& Yan, Y. (2015). Advertising value and credibility transfer: attitude towards web advertising and online information acquisition. Behaviour \& Information Technology, 34(5), 520. 


\section{APPENDIX}

\section{Research Questionnaire}

Please answer the following questions sincerely and accurately. The collected data will be confidential and will be used for scientific research only.

Please indicate your agreement / disagreement on the following statements regarding Social Network Sites advertisements (SNS Ads).

SNS (ex: Facebook, Instagram, YouTube, Twitter, Google plus)

\begin{tabular}{|c|c|c|c|c|c|c|}
\hline $\mathbf{S}$ & & $\begin{array}{l}\text { Strongly } \\
\text { disagree } \\
\text { (1) }\end{array}$ & $\begin{array}{l}\text { Disagree } \\
\text { (2) }\end{array}$ & $\begin{array}{l}\text { Neutral } \\
\text { (3) }\end{array}$ & $\begin{array}{l}\text { Agree } \\
\text { (4) }\end{array}$ & $\begin{array}{l}\text { Strongly } \\
\text { Agree } \\
\text { (5) }\end{array}$ \\
\hline INF1 & $\begin{array}{l}\text { SNS ads are a } \\
\text { valuable source of } \\
\text { product/service } \\
\text { information }\end{array}$ & & & & & \\
\hline INF2 & $\begin{array}{l}\text { SNS ads provide } \\
\text { me with complete } \\
\text { information }\end{array}$ & & & & & \\
\hline INF3 & $\begin{array}{l}\text { SNS ads help keep } \\
\text { me up to date }\end{array}$ & & & & & \\
\hline INF4 & $\begin{array}{l}\text { SNS ads provide } \\
\text { me with accurate } \\
\text { information }\end{array}$ & & & & & \\
\hline INF5 & $\begin{array}{l}\text { SNS ads are a } \\
\text { convenient source } \\
\text { of product/service } \\
\text { information }\end{array}$ & & & & & \\
\hline INF6 & $\begin{array}{l}\text { SNS ads provide } \\
\text { me with timely } \\
\text { information }\end{array}$ & & & & & \\
\hline INF7 & $\begin{array}{l}\text { SNS ads provide } \\
\text { me with relevant } \\
\text { product / service } \\
\text { information }\end{array}$ & & & & & \\
\hline INF8 & $\begin{array}{l}\text { SNS ads provide } \\
\text { me with reliable } \\
\text { information }\end{array}$ & & & & & \\
\hline CRD1 & $\begin{array}{l}\text { I use SNS ads as a } \\
\text { reference for } \\
\text { purchasing }\end{array}$ & & & & & \\
\hline
\end{tabular}


The effect of social $\ldots$ Dr Rasha H.A \& Dr. Madiha Metawie Accepted date 16/9/2020

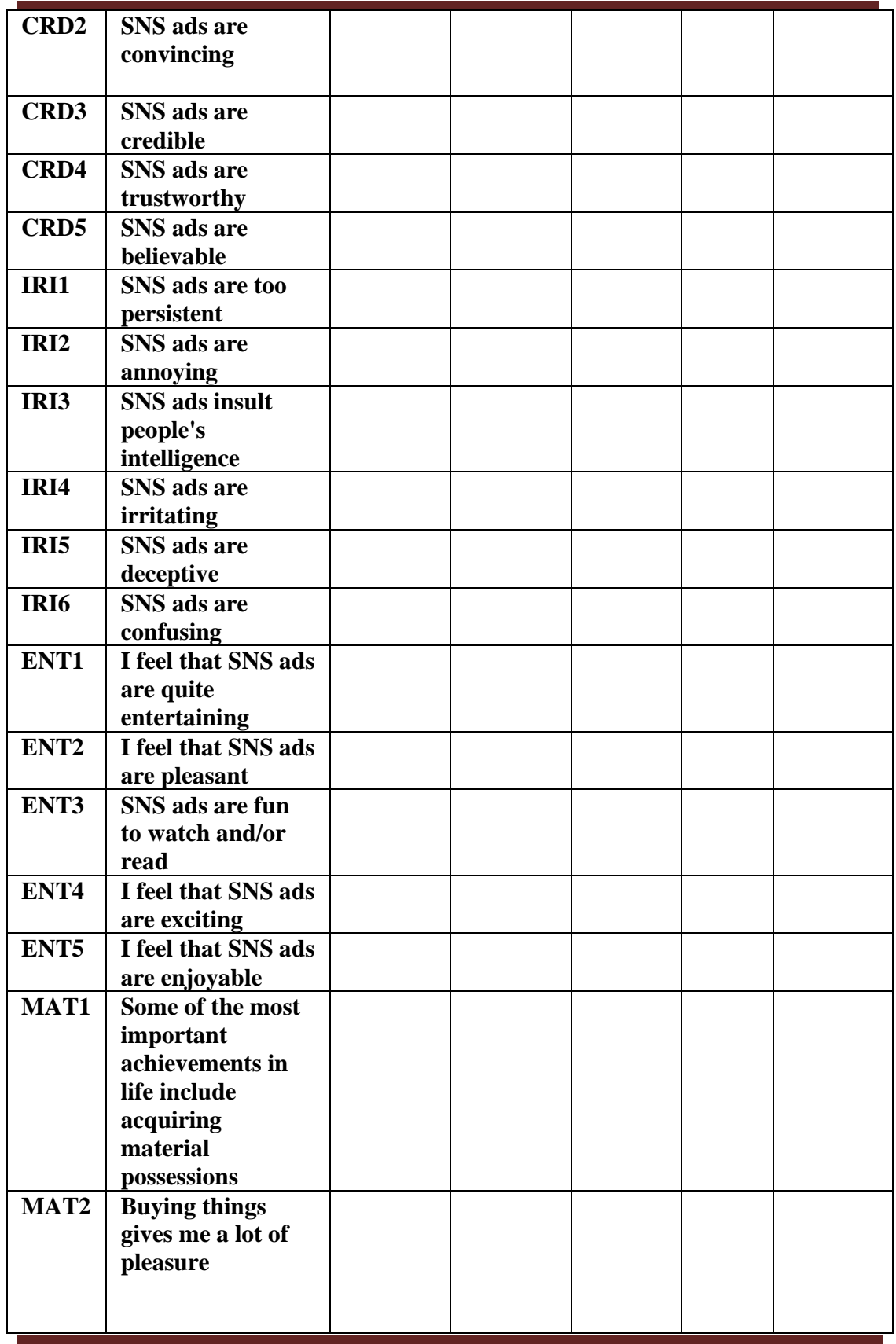

Scientific Journal for Economic\& Commerce 
The effect of social $\ldots$ Dr Rasha H.A \& Dr. Madiha Metawie Accepted date 16/9/2020

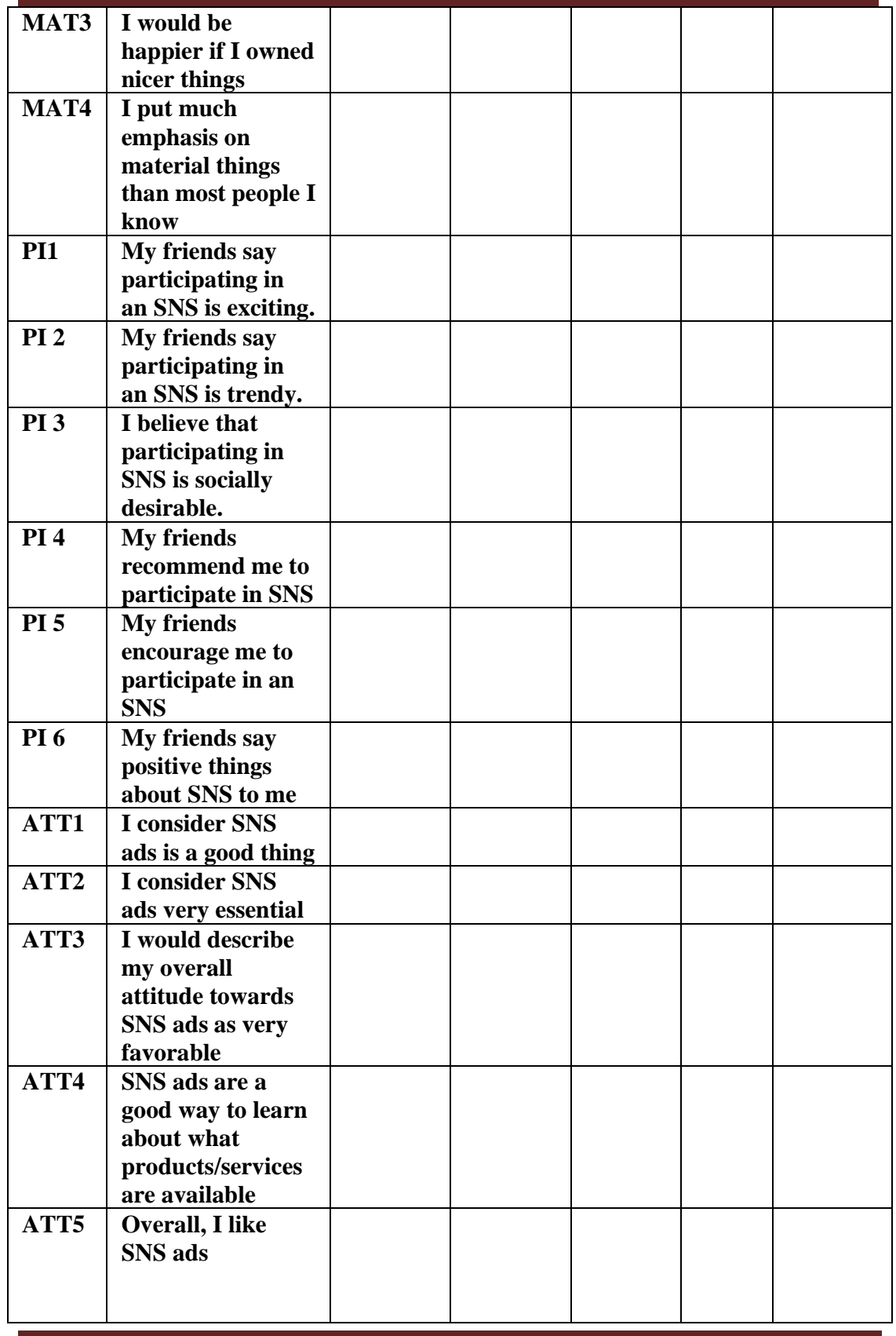

Scientific Journal for Economic\& Commerce 
The effect of social $\ldots$ Dr Rasha H.A \& Dr. Madiha Metawie Accepted date 16/9/2020

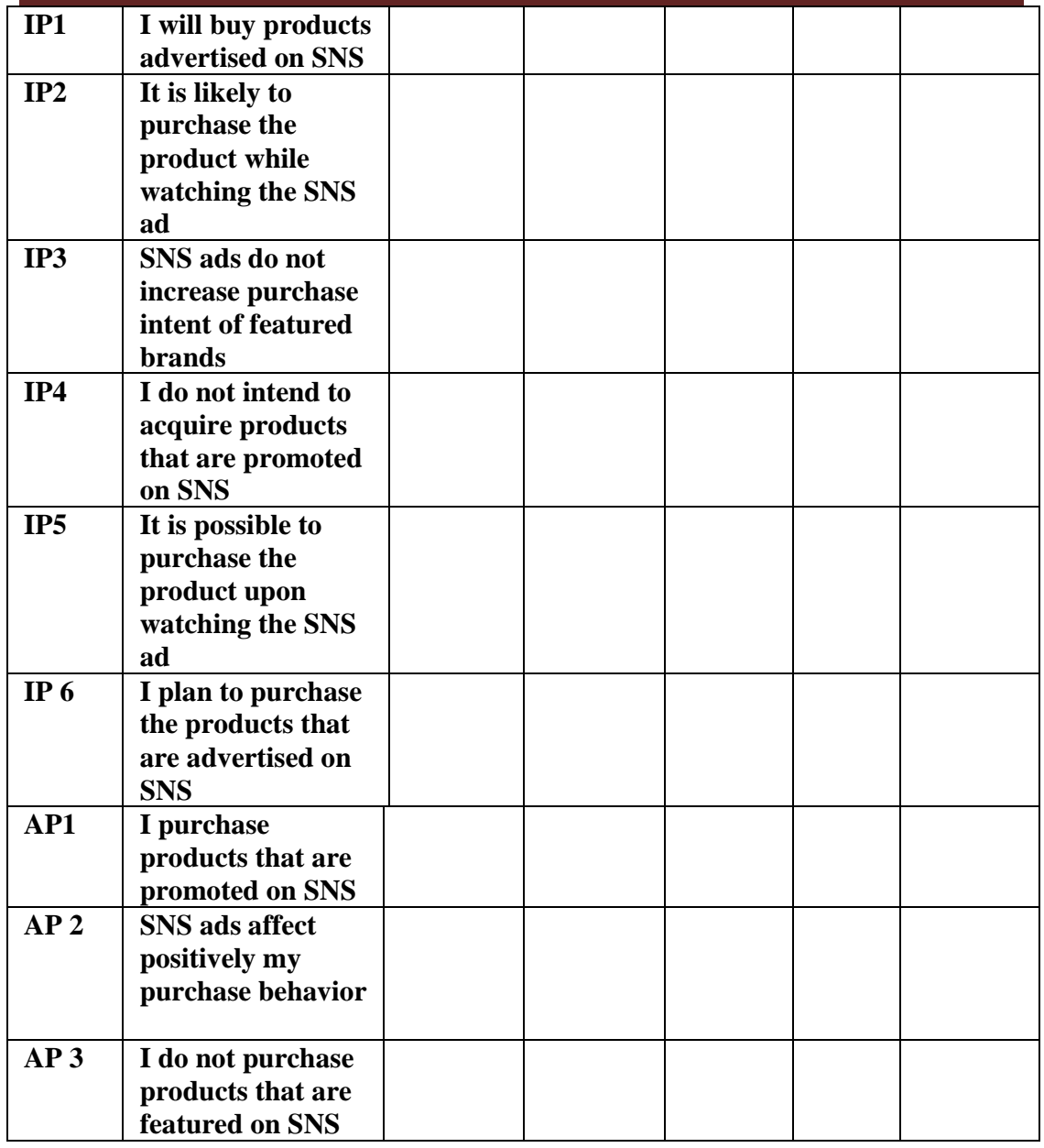
Gender $\square$ Male
$\square$ Female

From the following please indicate to which age group you belong?
$\square$ 18-22 years
$\square 23-27$ years
$\square$ 28- 32 years
$\square 33$-37 years
$\square 38-42$ years
$\square 42$ and above 
Please indicate what level of education you have attained?

$\square$ High School $\square$ Bachelor / License

$\square$ Postgraduate Degree $\quad \square$ Other

From the following, please choose the most frequently used SNS
$\square$ Facebook
$\square$ Instagram
$\square$ Twitter
$\square$ YouTube

$\square$ Google Plus

Please indicate the length of usage of your favorite SNS:

$\square$ Less than one year

$\square$ 1-2 years

$\square$ More than 2 years

$\square$ Have an account but do not use it

Please indicate the frequency of using your favorite SNS:
$\square$ Several times a day
$\square$ About once a day
$\square$ Every few days
$\square$ Once a week
$\square$ Less often

Do you frequently click on SNS Ads?

$\square$ I never have

$\square$ I have clicked a few times

$\square$ I often click on them

$\square$ I click (nearly) every time I log in

$\square$ I Less often click on them 